\title{
Strategy for Mitigating Landslide Disaster Risk through Improving the Status of Disaster Resilient Villages (DESTANA) Case Study in Kemuning Village, Ngargoyoso District, Karanganyar Regency
}

\begin{abstract}
Pipit Wijayanti, Rita Noviani, Anton Subarno, Fajar Dwi Prasetya, Hafidz Habibulloh, Muhammad Ikyu Arqie Ramadhan, Nur Fadillah, Panca Rizky Ayu Ramadhany, Pundung Setia Lesana, Putri Mariamulia Utami, Riksa Histhika, Rochadi Setyo Wibowo, Siti Setiyowati
\end{abstract}

Universitas Sebelas Maret

pipitwijayanti@staff.uns.ac.id

\section{Article History}

accepted 31/08/2020

published 28/10/2020

\begin{abstract}
Kemuning Village is one of the areas with the highest potential for landslides in Ngargoyoso District, Karanganyar Regency. This service activity aims to help institutional strengthening of the Tangguh Disaster Village (Destana) in disaster planning at the village level in the context of increasing preparedness and disaster management of landslides. The activity was carried out in Kemuning Village with an implementation time of 1 month The research method through open interviews, field observations, document review, and then analyzed descriptively qualitatively. The results of the disaster resilience assessment indicate that Kemuning Village is included in the category of Main Disaster Resilient Village. Based on the assessment analysis presents indicators of disaster management systems, disaster risk management, quality and basic access in the village is still lacking so it needs to be improved. The target of service outcomes obtained from this activity is to optimize the role of disaster resilient villages to reduce the risk of landslide disasters.
\end{abstract}

Keywords : Landslide Disaster, Tangguh Disaster Village, KKN, PRB.

\begin{abstract}
Abstrak
Desa Kemuning merupakan salah satu daerah dengan potensi paling tinggi tanah longsor di Kecamatan Ngargoyoso, Kabupaten Karanganyar. Kegiatan pengabdian ini bertujuan membantu penguatan kelembagaan Desa Tangguh Bencana (Destana) dalam perencanaan kebencanaan di tingkat desa dalam rangka peningkatan kesiapsiagaan dan penanggulangan bencana tanah longsor. Kegiatan dilaksanakan di Desa Kemuning dengan waktu pelaksanaan selama 1 bulan. Metode penelitian melalui wawancara terbuka, observasi lapangan, telaah dokumen, dan selanjutnya dianalisis secara deskriptif kualitatif. Hasil penilaian ketangguhan bencana menunjukkan bahwa Desa Kemuning termasuk dalam kategori Desa Tangguh Bencana Utama. Berdasarkan analisis penilaian menyajikan indikator sistem penanggulangan bencana, pengelolaan resiko bencana, kualitas dan akses dasar di desa tersebut masih kurang sehingga perlu ditingkatkan. Target luaran pengabdian yang diperoleh dari kegiatan ini adalah mengoptimalkan peran desa tangguh bencana untuk pengurangan risiko bencana tanah longsor.
\end{abstract}

Kata kunci: Bencana Tanah Longsor, Desa Tangguh Bencana, KKN, PRB.

Social, Humanities, and Education Studies (SHEs): Conference Series https://jurnal.uns.ac.id/shes

p-ISSN 2620-9284 e-ISSN 2620-9292 


\section{PENDAHULUAN}

Pada periode tahun antara 2005 sampai dengan tahun 2015 terdapat lebih dari $78 \%$ (11.648 kali) kejadian bencana yang merupakan bencana hidrometeorologi. Hanya sekitar 22\% (3.810 kali) kejadian bencana yang merupakan bencana geologi. Kelompok bencana geologi yang sering terjadi adalah gempa bumi, tsunami, letusan gunung api, dan tanah longsor (DIBI-BNPB, 2016).

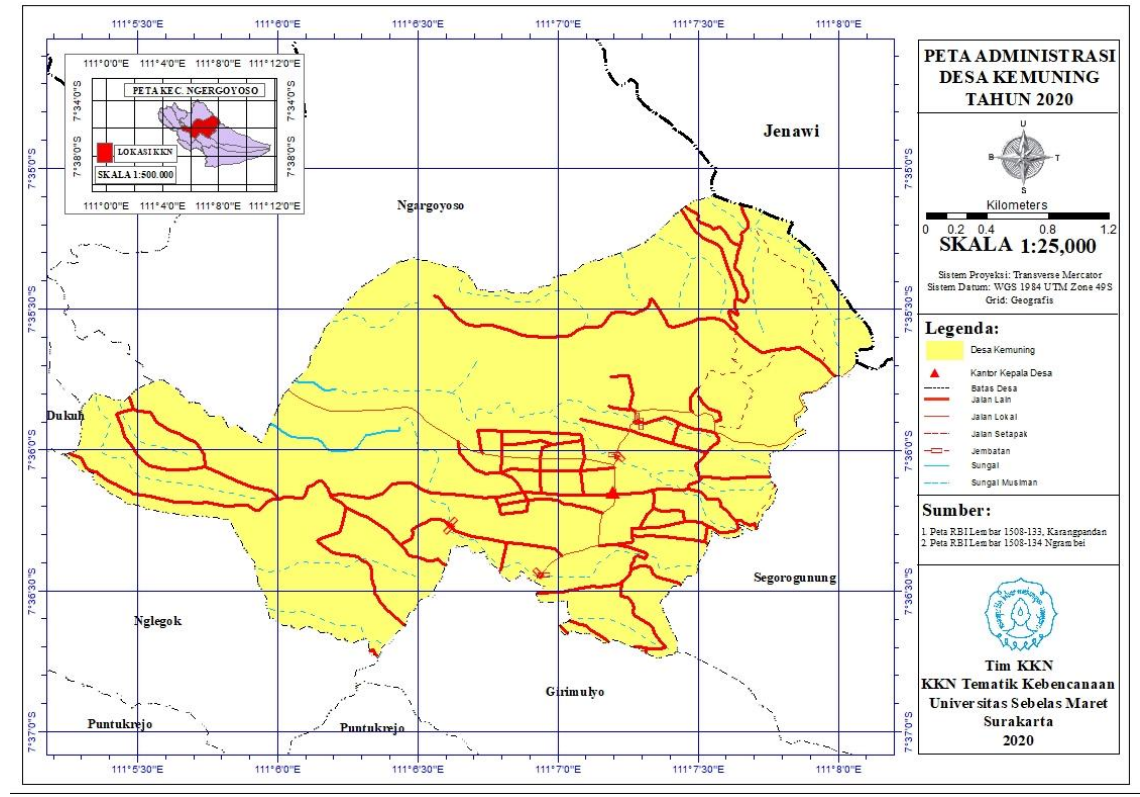

Gambar 1. Peta Administrasi Desa Kemuning, 2020

Desa Kemuning merupakan salah satu desa yang ada di Kecamatan Ngargoyoso, Kabupaten Karanganyar, Provinsi Jawa Tengah. Desa tersebut terletak di antara, yaitu sebelah utara Kecamatan Jenawi, sebelah selatan Desa Girimulyo, sebelah barat Desa Ngargoyoso, dan sebelah timur Desa Segoro Gunung. Luas wilayah administratif desa tersebut adalah $669,207 \mathrm{~km}^{2}$. Letak topografis berada di tanah pegunungan dengan ketinggian 800-1500 m di atas permukaan laut (dpl) dengan kemiringan 30\%-40\% dan ketinggian kurang lebih $1000 \mathrm{~m}$. Curah hujan merata sepanjang tahun antara 3000-4000 mm per tahun tanpa musim kemarau yang panjang. Keadaan angin normal dan intensitas pencahayaan sebesar $40 \%$. Suhu ratarata harian mencapai $20^{\circ} \mathrm{C}$ dan suhu tertinggi $25^{\circ} \mathrm{C}$. Biasanya potensi tanah longsor terjadi di daerah dataran tinggi. Jadi, dengan kondisi-kondisi di atas, Desa Kemuning berpotensi terjadi bencana tanah longsor.

Dengan potensi bencana yang dihadapi oleh masyarakat Kecamatan Kemuning tersebut, maka kesiapsiagaan masyarakat dan aparat pemerintah tingkat desa menjadi hal penting. Hal tersebut juga menjelaskan bahwa perencanaan kebencanaan menjadi urgen bagi masyarakat yang memiliki daerah dengan tingkat kerawanan yang tinggi. Jika tidak ada upaya mitigasi bencana, maka akan sering terjadi bencana yang berdampak negatif yang lumayan besar bagi kelangsungan hidup masyarakat di daerah tersebut. Pemerintah berupaya mengurangi risiko bencana melalui berbagai kegiatan PRB (Pengurangan Risiko Bencana) di daerah-daerah. Salah satu yang dilakukan adalah dengan peningkatan kapasitas masyarakat melalui Destana atau Desa Tanggung Bencana. Hal ini penting dilakukan karena Destana adalah desa atau kelurahan yang memiliki kemampuan mandiri untuk beradaptasi dan menghadapi ancaman bencana serta memulihkan diri dengan segera dari dampak bencana yang 
merugikan jika terkena bencana (BNPB, 2012). Destana memiliki lima komponen, yaitu legislasi, perencanaan, kelembagaan, pendanaan, pengembangan kapasitas, dan penyelenggaraan penanggulangan bencana. Pada tahun 2013 sampai dengan tahun 2018; BNPB, BPBD Jawa Tengah, dan BPBD Kabupaten telah membentuk 132 Destana atau rata-rata 22 desa per tahun.

Pemerintah tidak sanggup melaksanakan program Destana sendiri, sehingga memerlukan bantuan seperti KKN Tematik Kebencanaan yang dilakukan oleh sekelompok mahasiswa dengan didampingi oleh seorang dosen pembimbing. Selain itu, Mahasiswa dan dosen pembimbing tidak bisa bergerak tanpa partisipasi dari masyarakat. Masyarakat setempay perlu melakukan dukungan modal sosial dan sumber daya manusia (SDM) untuk merencanakan bermacam-macam kegiatan yang sekiranya dibutuhkan. Berdasarkan analisis situasi dan tinjauan berbagai informasi yang berkaitan dengan kondisi Destana di Desa Kemuning ditemukan beberapa hal, antara lain: (1) Tidak ada rencana penanggulangan bencana desa atau kelurahan yang menjadi bagian perencanaan pembangunan pada pemerintahan vertikal; (2) tidak adanya penyelarasan rencana penanggulangan bencana dan perubahan iklim antardesa atau antarkelurahan dalam kawasan; dan (3) tidak adanya mekanisme untuk mendeteksi peringatan dini terjadinya kemungkinan bencana pada skala desa atau kelurahan.

Tujuan penelitian ini adalah untuk memberikan rekomendasi peningkatan kapasitas Destana dalam PRB tanah longsor di Desa Kemuning. Destana akan dibentuk sesuai dengan parameter-parameter di desa tersebut, sehingga masyarakat mampu menghadapi ancaman bencana tanah longsor dan mempunyai kesiapsiagaan yang lebih mumpuni.

\section{HASIL DAN PEMBAHASAN}

Kegiatan ini di awali dengan Penilaian Ketangguhan Desa ditujukan untuk mengetahui posisi ketangguhan desa Kemuning khususnya dusun Sumbersari saat ini dengan 5 komponen, untuk kemudian merancang aksi-aksi yang dibutuhkan untuk meningkatkan ketangguhan desa.

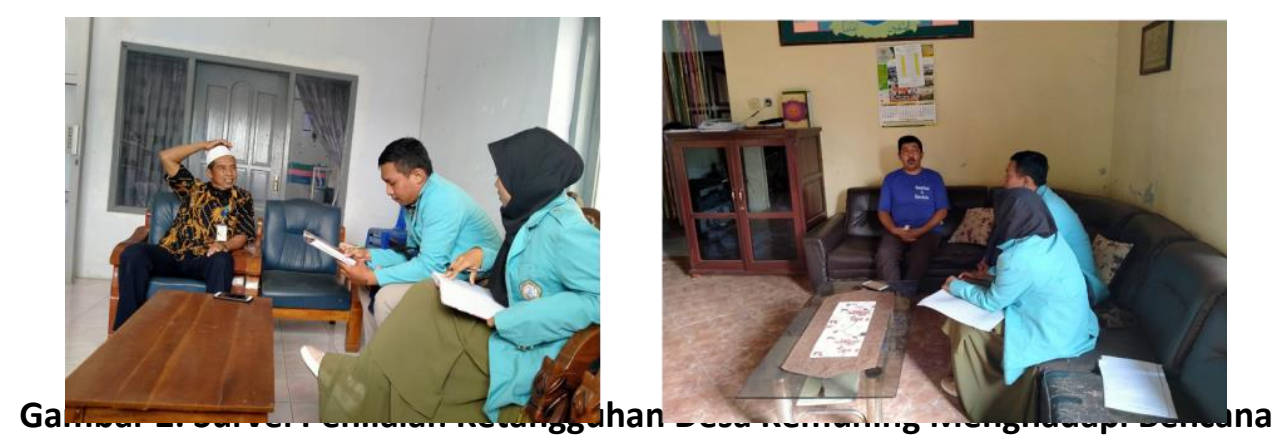

Sejumlah 112 pertanyaan yang mewakili 6 komponen Destana dibagikan. Penilaian dilakukan dengan menjawab pertanyaan-pertanyaan pada Form Kuesioner (Perka BNPB Nomor 1 Tahun 2012). Mengacu pada BNPB, tingkat ketangguhan desa dalam menghadapi bencana dibagi menjadi 3 kriteria yang ditunjukan pada tabel 1 .

Tabel 1. Tingkat Ketangguhan Desa dalam Menghadapi Bencana

\begin{tabular}{lc}
\hline \multicolumn{1}{c}{ Klasifikasi Skor Destana } & Skor \\
\hline Desa/Kelurahan Tangguh Bencana Utama & $>83,33$ \\
Desa/Kelurahan Tangguh Bencana Madya & $58,33-83,33$ \\
Desa/Kelurahan Tangguh Bencana Pratama & $58,33-83,33$ \\
\hline
\end{tabular}


Semua form kuisioner diolah, Jawaban yang telah terbukti, dimasukkan ke dalam Perangkat Analisa Penilaian Ketangguhan Desa. Untuk jawaban 'YA', diisi dengan angka 1, Untuk jawaban 'TIDAK' diisi dengan angka 0 . Penilaian ketangguhan desa/kelurahan diperoleh dari gabungan nilai seluruh indikator, sehingga dihasilkan nilai sebagai berikut:

Tabel 2. Penilaian Ketangguhan

\begin{tabular}{|c|c|c|c|c|}
\hline No & Komponen & $\begin{array}{c}\text { Indeks } \\
\text { Komponen }\end{array}$ & $\begin{array}{l}\text { Indeks } \\
\text { Desa } \\
\text { Tangguh }\end{array}$ & $\begin{array}{c}\text { Tingkat } \\
\text { Ketangguhan } \\
\text { Desa }\end{array}$ \\
\hline 1 & $\begin{array}{l}\text { Kualitas dan Akses Layanan } \\
\text { Dasar }\end{array}$ & 1,00 & \multirow{5}{*}{86,89} & \multirow{5}{*}{$\begin{array}{l}\text { Tangguh } \\
\text { Utama }\end{array}$} \\
\hline 2 & Dasar Sistem & 0,58 & & \\
\hline 3 & $\begin{array}{l}\text { Penanggulangan Bencana } \\
\text { Pengelolaan Risiko Bencana }\end{array}$ & 1,00 & & \\
\hline 4 & Kesiapsiagaan darurat & 0,83 & & \\
\hline 5 & Kesiapsiagaan Pemulihan & 0,72 & & \\
\hline
\end{tabular}

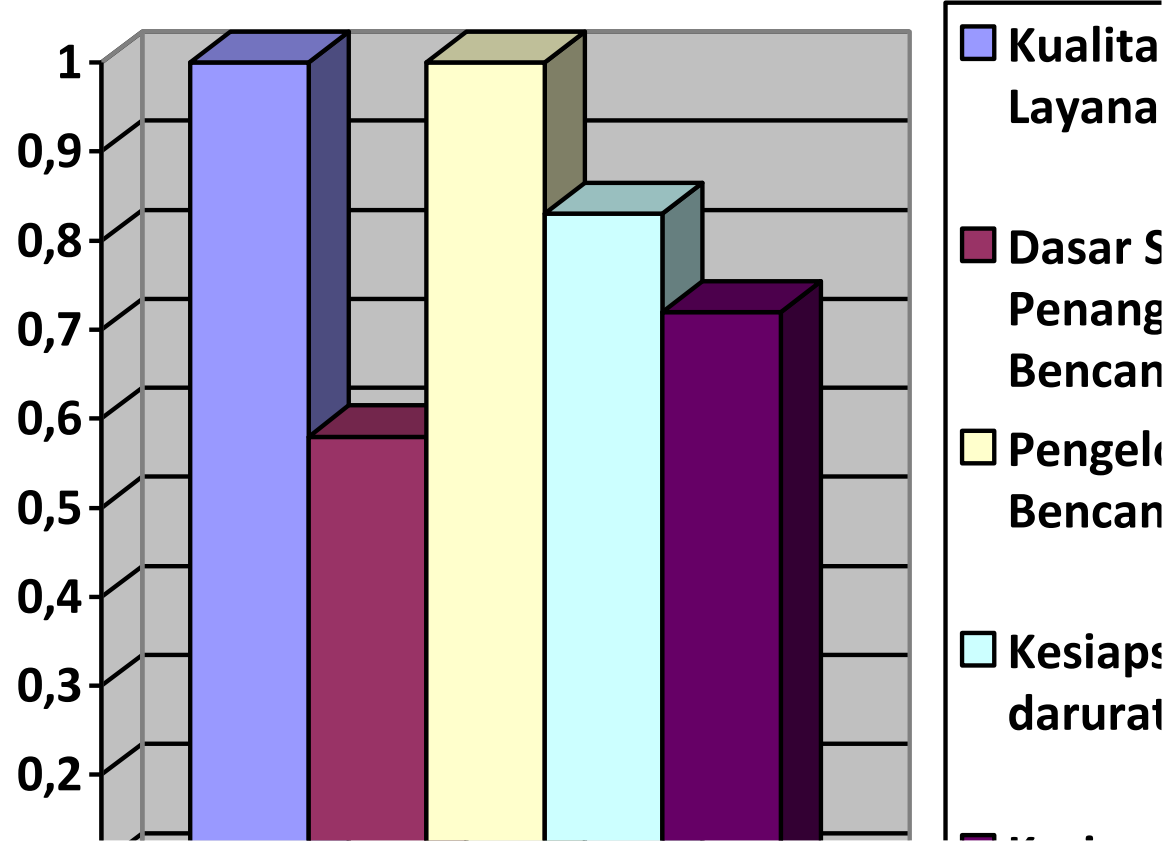

Gambar 3. Indeks Per Komponen Ketangguhan Desa Kemuning Menghadapi Bencana

Berdasarkan tingkat ketangguhan desa dalam menghadapi bencana, hasil penilaian ketangguhan bencana menunjukkan bahwa Desa Kemuning termasuk dalam kategori Desa Tangguh Bencana Utama. Tabel analisis penilaian menyajikan kualitas dan akses layanan dasar, indikator sistem penanggulangan bencana, pengelolaan resiko bencana, kualitas dan akses dasar. Dari tabel hasil analisis juga didapatkan indeks perkomponen dari desa kemuning dan rekomendasi aksi, sehingga dapat di ketahui komponen-kompenen mana saja yang perlu ditingkatkan kapasitasnya.

Terlihat aspek yang kurang meliputi sistem penanggulangan bencana, pengelolaan resiko bencana, kualitas dan akses dasar di Desa Kemuning, Kecamatan Ngargoyoso, Kabupaten Karanganyar dalam pengurangan risiko bencana tanah longsor. 
Tahapan selanjutnya yaitu dilaksanakan kegiatan yang membantu penguatan kelembagaan Desa Tangguh Bencana (Destana) perencanaan kebencanaan di tingkat desa dalam rangka peningkatan kesiapsiagaan dan penanggulangan bencana tanah longsor di Desa Kemuning. KKN tematik UNS berkoordinasi dengan BPBD Karangayar, Perangkat Desa Kemuning, BABINKAMTIMNAS desa Kemuning, Relawan dan penggiat lingkungan di Kemuning. Target luaran meliputi sosialisasi, FGD, pelatihan, dan pelaksanaan kegiatan kebencanaan. Kegiatan sosialisasi kebencanaan meliputi sosialisasi mengenai kebencanaan tanah longsor yang disampaikan oleh BPBD Karangayar dan sosialisasi terkait Covid-19 mengingat KKN dilaksanakan ditengah kondisi pandemi. Kegiatan dilaksanakan di Balai Desa Kemuning, diikuti oleh perwakilan tim KKN Tematik UNS dan warga setempat melalui media Zoom Meeting.

Kegiatan dilanjutkan dengan sosialisasi mengenai Covid-19 dari LPPM Universitas Sebelas Maret terkait informasi menegnai upaya penanggulangan risiko bencana pada sektor pariwisata. Mengingat Desa Kemuning merupakan salah satu sektor objek wisata yang terkenal di Kabupaten karangayar, maka perlu adanya pencerdasan terhadap pengelolaan objek wisata dimasa pandemi. Sosialisasi ini dilaksanakan guna meningkatkan wawasan dan keterampilan untuk mengelola risiko bencana melalu edukasi, sosialisasi, literasi kebencanaan dan informasi terkait upaya penanggulangan risiko bencana pada sektor pariwisata.

Dalam kegiatan FGD KKN Tematik UNS juga dilakukan Forum Pengurangan Resiko Bencana (FPRB). Pengelolaan risiko bencana berbasis forum yang menempatkan masyarakat sebagai aktor penting merupakan strategi utama dari inisiatif pengelolaan risiko bencana untuk membangun ketangguhan terhadap bencana. Tahapan pembentukan forum dimulai dengan merujuk pada hasil kajian risiko bencana tanah longsor yang terjadi di desa Kemuning. Hasil kajian menunjukkan adanya kebutuhan masyarakat dusun Sumbersari untuk menjamin pelaksanaan pengurangan risiko bencana di tingkat Desa/Kelurahan. Hasil dari kajian tersebut kemudian dibawa dalam rembug dusun dan desa, dan disepakati adanya wadah seluruh elemen masyarakat untuk mengurangi risiko bencana tanah longsor.
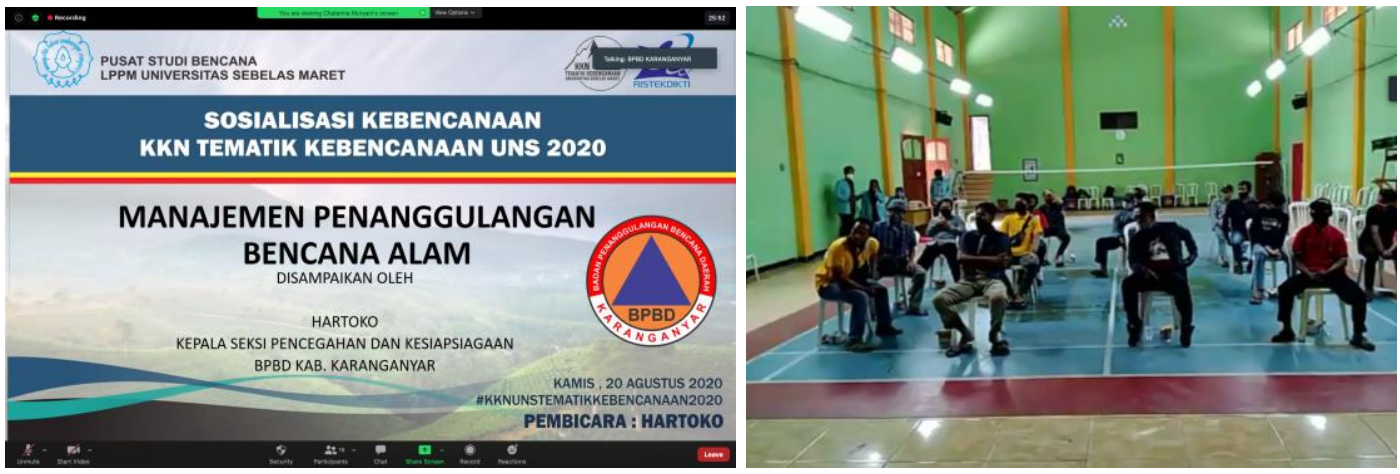

Gambar 4. Pelaksanaan Sosialisasi Kebencanaan dengan Format Webinar. 
Optimalitas peran serta forum pengelolaan risiko bencana desa atau kelurahan dalam mewujudkan rencana pembangunan maka dibentuk Forum Group Discussion (FGD) yang dilaksanakan dengan kegiatan meliputi sosisalisasi mengenai pembentukan tim penanggulangan resiko bencana, sosialisasi penanggulangan resiko bencana kesiapsiagaan bencana secara berkala dan berkelanjutan tingkat desa/kelurahan. Dalam forum grub discussion, untuk tersedianya mekanisme mendeteksi dini kemungkinan terjadinya bencana pada skala desa/kelurahan, maka diadakan kegiatan pelatihan menggunakan alat pendeteksi peringatan dini tanah longsor (ews) early warning system. Alat ini dipasang ditempat yang rawan lonsor serta masih pergerakan tanahnya. Dengan alat ini diharapkan dapat mendeteksi kemungkinan akan terjadinya bencana serta dapat memperkecil korban jiwa ketika terjadi tanah longsor. Sistem kerja alat ini mengelurkan bunyi peringatan ketika terjadi retakan dan pergeseran tanah. KKN tematik UNS juga membuat pemetaan resiko bencana rawan longsor. Mengambil sumber dari BPBD Karangayar dan pihak perangkat desa, masyarakat desa serta literatur terpercaya dengan kondisi dilokasi. Jadi selain pemasangan ews (ealy warning system) dititik-titik yang benar rawan longsor, terdapat pendataan tempat yang terindikasi rawan longsor sehingga dapat meningkatkan rencana evakuasi masyarakat.

Tersedianya rencana evakuasi masyarakat yang dapat digunakan sebelum dan pada saat bencana terjadi, maka diadakan pemasangan jalur, rambu, dan titik evakuasi di tingkat kelurahan khususnya daerah rawan bencana tanah longsor tepatnya di dusun Sumbersari. Jalur, rambu, dan titik evakuasi titik aman berfungsi untuk mekanisme penyebaran arahan evakuasi sehingga mudah diakses dan dipahami semua pihak termasuk kelompok rentan.

\section{SIMPULAN}

Dari lima komponen penilaian ketangguhan bencana didapat indeks komponen kualitas dan akses layanan dasar Desa Kemuning, Kecamatan Ngargoyoso, Kabupaten Karanganyar sangat baik sebesar 1,0. Sedangkan yang masih kurang yaitu pada komponen pengelolaan risiko bencana dengan indeks komponen 0,58. Tingkat ketangguhan Desa Ngargoyoso termasuk dalam kategori Desa Tangguh Utama dengan dengan diperoleh indeks desa tangguh sebesar 86,89.

\section{DAFTAR PUSTAKA}

Badan Nasional Penanggulangan Bencana. 2012. Peraturan Kepala BNPB No 1 Tahun 2012 tentang Pedoman Umum Desa/Kelurahan Tangguh Bencana. BNPB. Jakarta. 2012.

Badan Nasional Penanggulangan Bencana. 2012. Pedoman Sistem Peringatan Dini Berbasis Masyarakat. http://www.bnpb.go.id.

Badan Nasional Penanggulangan Bencana. 2009. Rencana Nasional Penanganan Bencana 2010- 2014. Jakarta.

Sariyanti, S. 2016. Pengembangan Desa Kemuning sebagai Objek Wisata Minat Khusus Industri Teh. Diambil pada 29 Agustus 2020 dari http://eprints.ums.ac.id/41229/5/Bab\%201.pdf

Sorja Koesuma, Sarjoko Lelono, dkk. 2020. Pembentukan Desa Tangguh Bencana melalui Kuliah Kerja Nyata Tematik Pengurangan Risiko Bencana di Kabupaten 
SHEs: Conference Series 3 (1) (2020) 307 - 313

Purbalingga. Pusat Studi Bencana, Lembaga Penelitian, dan Pengabdian kepada Masyarakat Universitas Sebelas Maret.

Undang-Undang RI No.24 Tahun 2007. 2007. Penanggulangan Bencana: Jakarta 